\title{
NOTES
}

\section{NOTES TO ACCOMPANY WHITMAN'S LETTER OF JULY 28, 1891}

Whitman's July 28, 1891, previously unpublished letter to an unidentified correspondent, reproduced on the back cover of this issue, is written on a slip of yellow proof paper. It is in the possession of Mr. and Mrs. Charles Rosenthal of Binghamton, New York, and is reprinted with their permission. Mrs. Rosenthal's father, Dr. Jacob Solis-Cohen of Philadelphia, bought or received the letter in 1945 from his cousin A.S.W. Rosenbach, a Philadelphia rare book dealer, and gave it as an engagement present to Charles Rosenthal, his future son-in-law. Elizabeth Fuller, acting curator of the Rosenbach Library, says that the letter was originally purchased from a collector named William Bixby. The letter reads as follows:

Camden July 28 '91

Lou was here to-day, but I was lying down \& she did not come up. Nothing very different with me-the weather is better, not such terrible heat-Did you get the Lippincott magazine for August? - good, cheery letters f'm England to-day - (I have lots of nuisance letters applications for autographs - never answer them)-was took out two hours Saturday, horse \& wagon, to a pleasant quiet water side shore-Best love to you -\$2 enc'd Walt Whitman

It is clear that the "unidentified correspondent" is in fact Hannah Heyde, Whitman's sister, who was ill a bit earlier in 1891 and to whom Whitman was exceedingly loyal. His final four letters in Edwin Haviland Miller's edition of The Correspondence are to Hannah, and in each, with his remarkable dutifulness, he enclosed money, always using the same characteristic abbreviation that he uses in this letter - "\$2.00 enc'd." Whitman's letters to Hannah are marked by a special restraint, no theatricality, only tenderness and a quiet, mildly detailed brevity. During this period, he signed his name in full, Walt Whitman, even to his sister, as if he were signing a painting (at other times, he used just his initials). This letter is particularly subdued and gentle, confirming the impression Horace Traubel records in his journal entry that day, quoting Whitman's personal physician Dr. Longaker, who had just seen the poet and enjoyed "the pleasantest talk I have ever had with him-he looked so gentle and fine under the gaslight there."2

Whitman's letter is written on paper with an Epictetus letterhead, which Whitman used regularly during the last year of his life. I have seen it on other letters to Hannah (July 13, 1891, and September 1, 1891). The letterhead is an excerpt from the May 7, 1891 Boston Evening Transcript, offering Whitman's Americanization of the Epictetus Fragment 26, Marcus Aurelius 4, 41: "The Epictetus saying, as given by Walt Whitman in his own quite utterly dilapidated physical case, is 'a little spark of soul dragging a great lummox of corpse-body to and fro around.' "3 Throughout his writing life, and especially 
toward the end, Whitman identified with the crippled slave; he reread Epictetus with great enthusiasm in T.W.H. Rolleston's translation of Encheiridion (1881), which Rolleston sent Whitman in Camden. Whitman's bond with Rolleston's Epictetus is important (Rolleston even quotes Whitman in his introduction to Encheiridion). Whitman closely read and kept notes on Rolleston's translation, writing on the front endpaper: "From 1881-1888 have had this little vol at hand or in my hand often all these years. Have read it over and over." ${ }^{4}$ Whitman's bond to Epictetus is clear; as the poet wrote to J.W. Wallace in May of 1891, "I guess I have a good deal of feeling of Epictetus \& stoicism, or tried to have." Whitman wrote a spontaneous review of Epictetus on the second front endpaper of the Rolleston translation: "Be bold bold bold bold / be not too bold."

The day Whitman wrote this letter to Hannah was a day of stoicism, of mild doubt, restraint and regret, of solitude and reflectiveness. He stayed in bed more than usual, and his sister-in-law Louisa, on one of her regular visits, did not even come upstairs to see him. Lou visited Whitman every couple of weeks, coming down from Burlington, New Jersey, a trip of about eighteen miles, less than an hour on the Camden and Amboy railroad. ${ }^{6}$ Louisa and Whitman's brother George lived on a farm; George and Walt were not on good terms, and Louisa was Whitman's closest family visitor, regularly bringing various provisions. She had visited on July 13, bringing berries and chatting with Whitman, but this day he was asleep when she called. ${ }^{7}$

That evening, the poet remained reserved. When Traubel stopped by and asked if there was any news, Whitman retreated: "Why should you come to me-a hermit-for the news?" Later, he was stirred by the receipt of a letter from Dr. R.M. Bucke (who was in England), containing buoyant messages from his "Eagle College" fan club in Bolton, Lancashire. Letters from England at this time took about twelve days to arrive (this one came in ten), and Cunard claimed to have delivered seventeen million letters between the United States and England from 1840 to 1888, never losing a single mailbag. So Whitman carried on an active transatlantic conversation, but on this day his mood led him to be particularly resistant to the extravagant praise that had crossed the ocean: "But that is wrong wrong $-\mathrm{I}$ am no saint - no one knows this as well as I do-I am full of things which nice fellows do not ever learn to suspect." $\mathrm{He}$ emphasized that he wanted always to "pull in from extravagance." Everything that day stayed small-scale.

Even the weather was less intense than usual. In the letter, Whitman notes that "the weather is better, not such terrible heat." He often referred to the oppressive Camden summer heat. He spent most of his time on the second floor of a flat-roofed house near a fertilizer factory, and the winds carried industrial fumes from Philadelphia his way. He spoke to Traubel of the constant "noise, noise," and the nearby lowland marshes added humidity to the heat.

His weariness and wariness that day contrasted the energy and engagement of the previous weeks. The August Lippincott's Magazine that Whitman mentions to Hannah contains Traubel's extensive account of the poet's birthday, May $31,1891 .^{8}$ It was his seventy-second, and it was-as he knew it would be-his last. The publication of the record of the event was delayed a month because of Traubel's schedule, but as soon as it appeared, Whitman began 
talking the piece up in letters to a variety of friends. Traubel's working text for the article (now in the Library of Congress) reveals that Whitman in fact had a hand in writing it. Whitman's revisions are inserted here and there in the text; he deletes passages, adds comments, changes phrases (Traubel's "big fellows," for example, is revised by Whitman to read "mighty comrades"). Traubel's ten-page record of Whitman's last birthday party is supplemented by his journal, where he describes the planning, execution, and follow-up publicity for the event. Whitman had intended to come downstairs and mingle with the 35-40 guests for only a few minutes, but he stayed much longer: "When I started to go downstairs I was more for death than life-yet down once, the spigot out, I let forth a constant stream-even garrulity itself. It was an experience. What a triumph!" Doors in Whitman's house had to be removed to accommodate the crowd. The party capped off a festive week on Mickle Street, for only three days earlier Horace Traubel and Anne Montgomerie had been married in Whitman's bedroom.

When Whitman tells Hannah that he "was took out two hours Saturday, horse \& wagon, to a pleasant quiet water side shore," he concisely records what in Traubel's unpublished journal is a long and lovely entry. On July 25, the newlywed Traubels took Whitman on a day trip and asked him to choose the destination. In a carriage driven by Whitman's nurse Warrie Fritzinger, they went to Pea Shore, a three-mile journey that took them from urban through suburban and into rural areas; on the way out, they crossed over State Street Bridge and on the way back over Federal Bridge. They crossed the Camden and Amboy tracks below Fish House, near the brick and terra-cotta factories and the clay cliffs, and came right up to the Pea Shore on the Delaware River. The cove and its beach faced Petty's Island and the city of Philadelphia a mile across the river. People from Philadelphia would come to the Pea beach and pleasure grounds by ferry and train. The shore was named for the vegetable once grown there. From the shore, the cityscape offered a fine vista, which on this day Whitman relished as he did the many local American scenesresidential, natural, industrial, and human - that he encountered along the way. The day produced in Traubel language of great emotion and meaning; his journal entry of July 25 captures a haunting panorama.

Whitman had not been to Pea Shore for a long time. Their trip began about five in the afternoon and became a pageant as the citizens of Camden saluted the aged poet, and he them, when the wagon passed: "In Pavonia," Traubel writes, "he saluted everyone-was mostly saluted in return. Some gazed at him astonished-some curious-some knew him-I heard his name frequently used. One man called his wife to the window-another calls a child-another comes to the fence, says his 'good day' and gazes after us till we get at the turn of the road. In the meantime, sunset approaching and the glory and mist therewith." Here is an excerpt from Traubel's unpublished account of the trip:

5:10 p.m. To W.'s-Warrie driving up and Anne arriving about the same time. W. ready to come downstairs. Said to me as he buttoned his vest, "Things proper if not pretty here must be mended before a fellow goes on the streets." Kissed Anne and spoke loving words in the hallway. Got in carriage rather more readily than last week. Remarked, "I had been saying to Warrie that I thought not to go out at all, but" - with a laugh - "you see I obey superior orders." I mentioned Longaker's feeling that the trip would do him 
good. "Oh! The devil! I wonder if he knows that any better than I do?" Anne sat back with him -I in front with Warrie. Told her he had had a bad night. Uptown to State Street bridge and Pea Shore. We had asked him where to go. By his own word it was Pea Shore. Talked freely and without abatement the whole trip. We pointed out to him where we lived. He spoke of "the beautiful openness of things up here." Of one of the factories, "I don't know but the factories are the most beautiful buildings in Camden." To a great chimney which I pointed out as "better-handsomer-than an obelisk against the sky there," he said fervently, "You are right - grander-and with such a human look." I had jumped out of carriage to put a package in Post Office for him-addressed to Sarrazin - two three-cent stamps. Anne asked, "Is it Lincoln?" And his, "Yes, Abraham Lincoln-Abraham Lincoln" came in a tone which she afterwards called "music itself" and which she remarked, "Always characterizes his mention of the name." He was full of reminiscence-once we were out of Camden-very specific to Anne. "Look at the river, lying off there-flowing - and the city across - and the mist. It is a misty day, Horace! And off here-look how the road runs, curves, passes away into the horizon. And"-pointing to the curious rims of deep water-grass running all through the flats-"Leaves of Grass! The largest leaves of grass known! Calamus! Yes, that is calamus! Profuse, rich, noble-upright, emotional!" How he uttered that! "I have had many inquiries about that-questions of all sorts - from people here, from abroadwhere is it found? What is calamus? Even Mrs. Gilchrist. I don't know that it grows in such wealth over there, though I don't see why not. These democratic bottoms are full of it this side!" He dwelt on cloud, sky, fences, trees - read signs, saw distant steeples, chimneys of factories, curls of smoke-I meanwhile joking, "And yet you say, Walt, that your eyesight is about gone!"... So W. said, "Drive right close to the water, Warrie" - and there we were-Pea Shore at last. W. even elated-seemed to sniff in the air. . . . Then, "Oh! the great quiet here-not a sound but the curling up of the waters! After Mickle Street this is heaven! Night and day there, noise, noise, noise-hell's own noise. Just in the first light of day, when you get your first nap (the whole night bad! bad!) comes the huckster into the street-stands under your window-bawls for his life. And comes another-and they go apart about a hundred feet and then hold a great conflab-yelling, calling - their talk, then about their goods. And so on and so on! Yes, this is peace, peace! . . . Here is air, water, freedom! See the stretch of the city-above there clouds. Oh! the clouds! and the line of the shore, here! See, Anne-see the boats - the white sails. And you think, Horace, we can't get along the shore here? Well, we can't risk anything-I can't. So, Warrie, I would turn the horse-we must go back the same road." . . . Meanwhile W. took off his hat - the low light sweet air seized his filmy hair, casting it about his head its own way and grace. He kept hat off for a great part of the road back. . . . Drove on over Federal Street bridge and back of the railroad to Benson. No stoppage this time, though multitudinous salutations as we passed alongseveral children coming into the street to say some word-one boy to grab W.'s hand-another to stand near and ejaculate "Kris Kringle!"

State University of New York, Binghamton

MiLton KessLeR

\section{NOTES}

\section{See The Correspondence (New York: New York University Press, 1969), 5:276-277.}

2 Manuscript of Traubel's Camden journal, July 28, 1891. Papers of Horace L. and Anne Montgomerie Traubel, Manuscript Division, Library of Congress. All quotations from Traubel's journal are transcribed from this manuscript. My thanks to Alice Birney of the Library of Congress for her guidance. 
3 Epictetus, trans. W.A. Oldfather (London, 1921), 2:471. Oldfather's version: "You are a little soul, carrying around a corpse, as Epictetus used to say."

4 Encheiridion, trans. with notes by T.W.H. Rolleston (London, 1881). Whitman's copy, containing his notes, is in the Feinberg Collection, Library of Congress. For more on Whitman's debt to Epictetus, see George B. Hutchinson, "'The Laughing Philosopher': Whitman's Comic Repose," Walt Whitman Quarterly Review 6 (Spring 1989), 172-188.

5 Correspondence, 5:205.

6 I am grateful to Ed Fox of the Camden Historical Society and Doug Winterich of the Walt Whitman House in Camden for this and other historical details in this essay.

7 Correspondence, 5:226.

8 “Walt Whitman's Birthday," Lippincott's Magazine (August 1891), 229-239.

\section{AN UNKNOWN 1879 PROFILE OF WHITMAN}

While he "loafed" in St. Louis after his September, 1879 western excursion, Walt Whitman was the subject of two articles in the town's major newspaper, the St. Louis Post-Dispatch. The first, titled "Walt Whitman: His Ideas about the Future of American Literature" and published on October 17, 1879, is an important document because the poet discusses the state of American literature, as well as the future of politics and religion in America. Whitman used part of this interview in Specimen Days, and the whole article has been reprinted before, most recently in Walter H. Eitner's Walt Whitman's Western Faunt. ${ }^{1}$ Exactly two months later, the Post-Dispatch ran a follow-up piece, which has escaped notice by Whitman scholars. It is reprinted below, its first appearance since the original publication on December 17, 1879.

Unlike the first article, this second one does not contain an interview. Still, it is apparent from its obvious familiarity with Whitman that the reporter (anonymous, unfortunately) had followed the poet on his ramblings through the city. The bridge mentioned in the middle part of the article is the Eads Bridge over the Mississippi River; built between 1867 and 1874, it still stands today. A photograph of the bridge, circa 1874, is reprinted in Eitner's book (74).

The reference to "Gamaliel" in the last paragraph of the article is an allusion to the Pharisee who gave prudent advice in the Sanhedrin regarding the treatment of the followers of Jesus. It is clear from this allusion, and from the tone of the entire article, that Whitman was a very well-respected man during his sojourn in St. Louis between September 27, 1879, and January 5, 1880, when he departed for Camden.

WALT WhITMAN

What the Poet Does and How He Lives in St. Louis-Loafing and Inviting His Soul.

Walt Whitman, the poet, has become for the time being a denizen of the city of St. Louis. Readers of the Post-Dispatch will remember an interview that was had with him, some months ago, on his first settlement here, and since that time his kind and venerable face, with its snow-drift of flossy beard and hair, has become a familiar feature of the West End. 